\title{
EVALUASI PENGGUNAAN ANTIBIOTIK PASIEN DEMAM TIFOID DI INSTALASI RAWAT INAP RSUD KRATON PEKALONGAN TAHUN 2019
}

\section{EVALUATION OF THE USE OF ANTIBIOTICS IN THYPOID FEVER PATIENTS IN THE INPATIENT INSTALLATION OF KRATON PEKALONGAN HOSPITAL 2019}

\author{
Ulfatun Alkhodiyah, Ainun Muthoharoh, Yulian Wahyu Permadi, \\ St Rahmatullah \\ Universitas Muhammadiyah Pekajangan Pekalongan \\ Jl. Raya Ambokembang No.8 - Pekalongan \\ Email : alkhodiyahulfatun@gmail.com
}

Submitted : 14 Agustus 2020 Reviewes : 31 Agustus 2020 Accepted : 26 September 2020

\begin{abstract}
ABSTRAK
Demam tifoid adalah penyakit yang terjadi karena infeksi bakteri Salmonella thypi. Penggunaan antibiotik yang tidak tepat dapat merugikan pasien serta menyebabkan resistensi obat terhadap bakteri Salmonella thypi. Penelitian ini bertujuan untuk mengevaluasi dan menjadi prediksi awal kerasionalan penggunaan antibiotik pada pasien demam tifoid di Instalasi Rawat Inap RSUD Kraton Pekalongan tahun 2019. Penelitian ini merupakan jenis penelitian non eksperimental dengan pengumpulan data secara retrospektif dan dianalisis secara deskriptif. Pengambilan data secara acak sistematik dengan kriteria inklusi dan ekslusi yang telah ditentukan. Evaluasi dilakukan dengan cara menggunakan metode ATC/DDD sesuai dengan ketentuan WHO 2020. Sebanyak 96 data rekam medis yang masuk kriteria inklusi. Jenis kelamin perempuan sebanyak 53 pasien dengan kategori umur dewasa madya (41-60 tahun). Penyakit penyerta yang banyak dialami pasien adalah DHF, Bronchopneumonia dan Hipertensi. Sebanyak 70 pasien menjalani rawat inap selama 4-7 hari. Hasil evaluasi penggunaan antibiotik yang paling banyak digunakan untuk pengobatan demam tifoid di RSUD Kraton Pekalongan tahun 2019 adalah ceftriaxon dengan jumlah DDD/100 patient-days sebesar 45,23.
\end{abstract}

Kata kunci : Antibiotik, Demam tifoid, Evaluasi Kuantitatif

\begin{abstract}
Typhoid fever is a desease that occur due to Salmonella thypi bacterial infection. Improper use of antibiotics can harm patients and cause the drug resistance to Salmonella thypi bacteria. The aim of this study is to evaluate and predict the rationale for the use of antibiotics in typhoid fever patients in the Inpatient Installation of Kraton Pekalongan Hospital in 2019. This research type is a non-experimental research with retrospective data collection and descriptive analysis. Systematic random data collection with predetermined inclusion and exclution criteria. The evaluation was carried out by using the ATC/DDD method in accordance with WHO 2020 provisions. A total of 96 data medical record entered the inclusion criteria. There are 53 female patients in the middle adult age category (41-60 years). Another common comorbidities in patients are DHF, Bronchopneumonia and Hypertension. There are 70 hospitalized patients for 4-7 days. The antibiotic that is widely used at the Kraton Pekalongan Hospital in 2019 for typhoid is ceftriaxone with a total $\mathrm{DDD} / 100$ patient-days of 45,23 . The need for further prospective evaluation.
\end{abstract}

Keywords: Antibiotics, Typhoid Fever, Quantitative Evaluation 


\author{
Penulis Korespondensi : \\ Ulfatun Alkhodiyah \\ Universitas Muhammadiyah Pekajangan Pekalongan \\ Jl. Raya Ambokembang No.8 - Pekalongan \\ Email : alkhodiyahulfatun@gmail.com
}

\title{
PENDAHULUAN
}

Demam tifoid adalah penyakit yang terjadi karena infeksi bakteri Salmonella thypi dan umumnya menyebar melalui makanan dan minuman yang telah terkontaminasi bakteri tersebut, hal ini menyebabkan demam tifoid dapat menular dengan cepat (Hermayudi dan Ayu, 2017).

Prevalensi kasus bervariasi tergantung lokasi, kondisi lingkungan dan perilaku masyarakat setempat. Angka insidensi di seluruh dunia sekitar 17 juta per tahun dengan 600.000 orang meninggal karena penyakit ini. Prevalensi di Asia sekitar 900/100.000 penduduk per tahun. Indonesia merupakan negara endemik demam tifoid. Diperkirakan terdapat 800/100.000 penduduk setiap tahun yang ditemukan sepanjang tahun (Widoyono, 2011). Prevalensi demam tifoid di Kabupaten Pekalongan sebanyak 1.904 kasus dari 937.714 penduduk dengan angka insidensi sekitar 17 orang meninggal. Berdasarkan data yang diperoleh dari RSUD Kraton Kabupaten Pekalongan dari bulan Januari sampai Desember 2019 didapatkan kasus demam tifoid sebanyak 552 kasus di Instalasi Rawat Inap. Penggunaan antibiotik yang tidak tepat dapat merugikan pasien serta menyebabkan resistensi obat terhadap bakteri Salmonella thypi. Evaluasi penggunaan antibiotik dapat dilakukan secara kuantitatif dan kualitatif. Evaluasi penggunaan antibiotik secara kuantitatif dilakukan dengan menggunakan metode ATC/DDD untuk penggunaan antibiotika dengan cara menghitung DDD per 100 patient-days sehingga diketahui jenis dan jumlah antibiotik yang digunakan berdasarkan data pengukuran tersebut yang akan menjadi prediksi awal terkait dengan kerasionalan penggunaan antibiotika.

Penelitian ini dilakukan di RSUD Kraton Kabupaten Pekalongan yang merupakan salah satu diantara rumah sakit rujukan di Kabupaten Pekalongan dan jumlah kasus terbanyak selama periode 2019. Penelitian ini dilakukan pada bulan Mei tahun 2020. Penelitian sejenis juga pernah dilakukan oleh Nonita (2019) di Rumah Sakit Panti Rini Yogyakarta hasilnya menunjukkan bahwa antibiotik yang digunakan lebih tinggi daripada standar nilai yang telah ditetapkan dan antibiotik yang paling banyak digunakan adalah seftriakson. Perbedaan penelitian ini dengan penelitian sebelumnya adalah metode pengambilan sampel, metode evaluasi penggunaan antibiotik, waktu penelitian dan tempat penelitian.

\section{METODE PENELITIAN}

\section{Jalannya Penelitian}

1. Penentuan Sampel Penelitian

Pengambilan data dilakukan secara retrospektif dengan metode pengambilan data yang dilakukan secara acak sistematik dengan kriteria inklusi dan eksklusi yang telah ditentukan. Dalam tahap ini didapatkan data jumlah populasi penderita Demam Tifoid di RSUD Kraton sebanyak 552 pasien dengan rumus slovin, sebagai berikut :

$$
\begin{gathered}
\mathrm{N}=\frac{N}{1+N e^{2}} \\
\mathrm{~N}=\frac{552}{1+552\left(0,093^{2}\right)} \\
\mathrm{N}=95,59
\end{gathered}
$$

Berdasarkan perhitungan diatas maka sampel yang diambil sebanyak 96 data yang akan diambil perwakilan tiap bulannya 8 data yang masuk kriteria inklusi. Kriteria inklusi meliputi data rekam medik pasien usia 20-65 tahun dengan terdiagnosa medis demam tifoid dan atau tanpa penyakit penyerta, mendapatkan antibiotik dan yang 
menjalani perawatan di Instalasi rawat inap. Sedangkan kriteria eksklusi meliputi data rekam medik yang tidak lengkap atau terbaca dengan jelas.

2. Penelitian

Penelitian ini dilakukan berdasarkan data dari rekam medis pasien yang terdiagnosa Demam tifoid pasien dewasa. Data yang diambil untuk penelitian yaitu berdasarkan umur, jenis kelamin, diagnosa pasien, pemeriksaan fisik daftar obat dan lamanya waktu perawatan pasien rawat inap.

\section{Analisis Data}

Analisis data untuk penelitian ini menggunakan analisis univariat yang bertujuan untuk analisis setiap variabel yang akan diteliti secara deskriptif dengan pendekatan kuantitatif sehingga menghasilkan karakteristik pasien dan pola peresepan pasien yang menerima terapi antibiotik dalam bentuk persentase (\%) disertai penjelasan uraian. Tata cara analisis perhitungan dengan menggunakan metode DDD (Kemenkes, 2011) : kumpulkan data semua pasien yang menerima terapi antibiotik penyakit demam tifoid; kumpulkan lamanya waktu perawatan pasien rawat inap (total Length Of Stay, LOS semua pasien); hitung jumlah dosis antibiotik (gram) baik tunggal ataupun kombinasi selama dirawat; dan hitung DDD 100 patient-days melalui data yang berasal dari pasien menggunakan rumus $\left(\frac{\text { Jumlah gram antibiotik yang digunakan oleh pasien }}{\text { standar DDD WHO antibiotik dalam gram }} \times \frac{100}{\text { Total LOS }}\right)$

Hasil dari analisis deskriptif dan analisis dari metode ATC/DDD disajikan dalam bentuk tabel-tabel dan diagram yang mencakup: data demografi pasien, data pola peresepan dan data kuantitas penggunaan antibiotika dengan DDD/100 patient-days pada pasien demam tifoid yang menjalani rawat inap periode tahun 2019 ditinjau dari nilai standar DDD berdasarkan WHO (WHO, 2019). Selanjutnya disajikan menggunakan aplikasi Statistical Product and Service Solution (SPSS) untuk menghasilkan persentase berupa tabel distribusi frekuensi relatif. Metode ATC/DDD hanya digunakan untuk obat-obat yang memiliki kode Anatomical Therapeutic Chemical (ATC).

\section{HASIL DAN PEMBAHASAN}

Pada penelitian ini diperoleh data rekam medik pasien demam tifoid yang menjalani rawat inap di RSUD Kraton selama tahun 2019 sebanyak 282 rekam medis. Dari 282 rekam medis pasien tersebut sebanyak 96 pasien masuk dalam kriteria inklusi. Terdapat 186 rekam medis yang tereksklusi yang terdiri dari 11 rekam medis yang tidak ada ditempatnya, 5 rekam medis yang rusak, 80 rekam medis data yang sama dan 90 rekam medis yang tidak terbaca. Data pasien yang memenuhi kriteria inklusi kemudian disalin pada lembar form pengambilan data yang sudah disiapkan.

Pada bagian ini akan dibahas mengenai karakteristik pasien, pola peresepan pasien demam tifoid dewasa, evaluasi kuantitas penggunaan antibiotik pada pengobatan pasien demam tifoid dewasa serta keterbatasan penelitian.

\section{Karakteristik Pasien}

Karakteristik data rekam medis pasien demam tifoid terdiri dari jenis kelamin, umur, penyakit penyerta, lama hari rawat dan jumlah serta jenis antibiotik yang digunakan. Hasil data rekam medis jenis kelamin pasien demam tifoid yang menjalani rawat inap bisa dilihat pada Tabel I.

\section{Jenis Kelamin}

Tabel I. Karakteristik Pasien Terkait Jenis Kelamin

\begin{tabular}{cccc}
\hline \multirow{2}{*}{$\mathbf{N o}$} & $\begin{array}{c}\text { Jenis } \\
\text { Kelamin }\end{array}$ & $\begin{array}{c}\text { Jumlah Pasien } \\
(\mathbf{N = 9 6 )}\end{array}$ & $\begin{array}{c}\text { Persentase (\%) } \\
(\mathbf{N = 1 0 0 \% )}\end{array}$ \\
\hline 1. & Perempuan & 53 & 55,2 \\
2. & Laki-laki & 43 & 44,8 \\
\hline & Total & $\mathbf{9 6}$ & $\mathbf{1 0 0 \%}$ \\
\hline & & & (Data diolah, 2020)
\end{tabular}


Berdasarkan Tabel I diketahui bahwa pasien perempuan lebih banyak daripada pasien laki-laki. Pada pasien perempuan sebanyak 53 pasien dan pada pasien laki-laki sebanyak 43 pasien. Berdasarkan daya tahan tubuh perempuan lebih rentan untuk terkena demam tifoid dan dampak yang lebih berat. Hal ini berdasarkan salah satu teori yang menunjukkan bahwa Salmonella thypi masuk ke dalam sel-sel hati, maka hormon estrogen pada wanita akan bekerja lebih berat karena mengalami dua hal sekaligus (Pramitasari, 2013).

Banyaknya kasus kejadian demam tifoid pada pasien dewasa dapat disimpulkan bahwa tergantung dari jenis kelamin yaitu penyakit demam tifoid lebih banyak ditemukan pada perempuan daripada laki-laki hal ini sesuai dengan laporan Kementrian Kesehatan Republik Indonesia (2011) dan penelitian sebelumnya (Patattan, 2017).

2. Umur

Kategori umur pasien demam tifoid dewasa pada penelitian ini terbagi menjadi 3, yaitu masa dewasa awal (21-40 tahun), masa dewasa madya (41-60 tahun) dan masa dewasa lanjut (>60 tahun) (Jahya, 2011).

Tabel II. Karakteristik Pasien Terkait Umur

\begin{tabular}{ccccc}
\hline No & \multicolumn{2}{c}{ Kategori Umur } & Jumlah Pasien & Persentase (\%) \\
\cline { 2 - 5 } & Kategori & Umur & $(\mathbf{N = 9 6 )}$ & $\mathbf{N = 1 0 0 \%}$ \\
\hline 1. & Dewasa & $21-40$ & 45 & 46,9 \\
2. & $\begin{array}{c}\text { awal } \\
\text { Dewasa } \\
\text { madya }\end{array}$ & $\begin{array}{c}41-60 \\
\text { tahun }\end{array}$ & 48 & 50,0 \\
3. & $\begin{array}{c}\text { Dewasa } \\
\text { lanjut }\end{array}$ & $\begin{array}{c}>60 \\
\text { tahun }\end{array}$ & 3 & 3,1 \\
\hline & Total & & $\mathbf{9 6}$ & $\mathbf{1 0 0 \%}$ \\
\hline & & & (Data diolah, 2020)
\end{tabular}

Berdasarkan Tabel II pasien demam tifoid tertinggi pada usia 41-60 tahun sejumlah 48 pasien. Faktor banyaknya pasien usia 41-60 tahun atau masa dewasa madya dikarenakan pada usia tersebut pasien mulai mengalami penurunan daya tahan tubuh dan fungsi keadaan fisik sebelum memasuki masa dewasa lanjut (Jahja. 2011).

Hasil ini berbeda dengan penelitian yang dilakukan oleh Dewi (2018) dimana hasil yang didapatkan yaitu pasien demam tifoid yang tertinggi pada usia 26-35 tahun atau masa dewasa awal. Perbedaan ini dapat terjadi karena jumlah sampel yang diteliti tidak sama. Menurut kelompok umur, pasien paling banyak adalah usia remaja dan dewasa awal yang merupakan rentang usia yang lebih aktif dan lebih sering berada diluar rumah, sehingga lebih berisiko terinfeksi Salmonella typhi karena mengkonsumsi jajanan ataupun makanan sembarangan yang higienitasnya tidak terjamin (Adiputra et al, 2017).

\section{Penyakit Penyerta}

Penyakit penyerta pada pasien demam tifoid dewasa diketahui dari diagnosis lain selain demam tifoid oleh dokter.

Tabel III. Karakteristik Pasien Terkait Penyakit Penyerta.

\begin{tabular}{cccc}
\hline No & $\begin{array}{c}\text { Ada/Tidak Penyakit } \\
\text { Penyerta }\end{array}$ & $\begin{array}{c}\text { Jumlah Pasien } \\
\mathbf{N = 9 6}\end{array}$ & $\begin{array}{c}\text { Persentase (\%) } \\
\mathbf{N = 1 0 0 \%}\end{array}$ \\
\hline 1. & Ada & 53 & 55,2 \\
2. & Tidak Ada & 43 & 44,8 \\
\hline \multicolumn{2}{r}{} & $\mathbf{9 6}$ & $\mathbf{1 0 0 \%}$ \\
\hline & Total & & (Data diolah, 2020)
\end{tabular}


Pasien demam tifoid lebih banyak yang ada penyakit penyertanya yaitu sejumlah 53 pasien $(55,2 \%)$ dan yang tidak sebanyak 43 pasien $(44,8 \%)$. Banyaknya penyakit penyerta yang dialami oleh pasien dewasa demam tifoid dikarenakan daya tahan tubuh dan fungsi fisik yang mulai menurun sehingga lebih rentan untuk terkena penyakit penyerta selain diagnosa utamanya yaitu demam tifoid.

Penyakit penyerta yang dialami juga berbeda-beda tergantung dari kondisi masing-masing pasien demam tifoid.

Macam-macam dan jumlah penyakit penyerta yang terdiagnosa dapat dilihat pada Tabel IV di bawah berikut ini.

Tabel IV. Penyakit Penyerta Yang Dialami Pasien

\begin{tabular}{cccc}
\hline No & Penyakit Penyerta & Jumlah Pasien N = 96 & Persentase (\%) \\
$\mathbf{N}=\mathbf{1 0 0 \%}$
\end{tabular}

(Data diolah, 2020)

Penyakit penyerta yang paling banyak terjadi pada penelitian ini yaitu Bronchopneumonia, DHF dan Hipertensi sebanyak masing-masing 5 pasien. Berbeda menurut Prasetyono (2012) karena pasien demam tifoid biasanya akan mengalami penyakit penyerta baik diare atau sembelit. 
Hal ini dikarenakan masuknya bakteri Salmonella Typhi ke dalam tubuh manusia melalui makanan ataupun minuman yang telah terkontaminasi bakteri. Dalam lambung bakteri ini dimusnahkan, sebagian lolos sehingga masuk ke dalam usus dan selanjutnya berkembang biak. Bila respon imunitas humoral mukosa (IgA) usus kurang baik maka bakteri akan menembus sel-sel epitel (terutama sel M) dan selanjutnya ke lamina propia. Di lamina propia berkembang biak sehingga mengakibatkan gangguan pencernaan (Widodo, 2009).

\section{Pola Peresepan}

Pasien demam tifoid dewasa dalam penelitian ini mendapatkan pengobatan yang berbeda-beda. Pemberian masing-masing obat didasarkan pada kebutuhan dan diagnosa pasien.

4.1. Golongan dan Jenis Antibiotik

Tabel V. Jenis Antibiotik pasien demam tifoid dewasa

\begin{tabular}{ccccc}
\hline No & Nama Antibiotik & Kode ATC & $\begin{array}{c}\text { Jumlah Pasien } \\
\text { N = 96 }\end{array}$ & $\begin{array}{c}\text { Persentase (\%) } \\
\text { N= 100\% }\end{array}$ \\
\hline 1 & Ceftriaxon & J01DD04 & 59 & 61,5 \\
2 & Cefim & J01DD07 & 10 & 10,4 \\
3 & Ciprofloxacin & J01MA02 & 6 & 6,3 \\
& (Parenteral) & & & \\
4 & Ciprofloxacin (Oral) & J01MA02 & 5 & 5,2 \\
5 & Levofloxacin & J01MA12 & 5 & 5,2 \\
& (Parenteral) & & & 5,2 \\
6 & Moxifloxacin & J01MA14 & 5 & 3,1 \\
7 & Cefotaxim & J01DD01 & 3 & 1,0 \\
8 & Amoxicillin & J01CA04 & 1 & 1,0 \\
9 & Levofloxacin (Oral) & J01MA12 & 1 & 1,0 \\
10 & Metronidazol & J01XD01 & 1 & $\mathbf{1 0 0 \%}$ \\
\hline
\end{tabular}

(Data diolah, 2020)

Berdasarkan data hasil pengobatan pasien demam tifoid diatas, diperoleh penggunaan antibiotik untuk pasien demam tifoid paling banyak yaitu Ceftriaxon sebanyak 59 pasien yang terdiri dari pasien usia dewasa awal (2140 tahun) sebanyak 26 pasien, dewasa madya (41-60 tahun) sebanyak 30 pasien dan dewasa lanjut (>60 tahun) sebanyak 3 pasien. Ceftriaxon merupakan antibiotik golongan sefalosporin generasi ketiga. Penggunaan Ceftriaxon pada pasien demam tifoid yang menjalani rawat inap di RSUD Kraton tahun 2019 paling banyak, hal ini karena Ceftriaxon memiliki stabilitas yang tinggi terhadap bakteri, baik bakteri gram positif maupun bakteri gram negatif sehingga lebih efektif dalam membasmi bakteri penyebab demam tifoid (Pattan, 2017). Selain itu, penggunaan antibiotik ceftriaxon pada pasien demam tifoid juga dapat menurunkan suhu badan penderita dalam waktu singkat dibanding antibiotik kloramfenikol sehingga lebih efektif untuk diberikan. Antibiotik ceftriaxon mempunyai sifat yang menguntungkan yaitu dapat merusak struktur bakteri tanpa mengganggu sel tubuh manusia, memiliki spektrum luas dan resistensinya terhadap bakteri masih terbatas.

Antibiotik golongan sefalosporin lainnya yang digunakan yaitu cefotaxim dan cefim yaitu sebanyak 3 dan 10 pasien. Cefotaxim memiliki aktivitas yang sama dengan ceftriaxon, namun memiliki waktu paruh $(\mathrm{t} t / 2)$ yang lebih pendek (Purwaningsih et al, 2015). Sedangkan ceftriaxon merupakan antibiotik yang mengandung cincin beta lactam dan merupakan spektrum luas sehingga 
sampai saat ini golongan sefalosporin generasi ketiga yang terbukti efektif untuk mengobati demam tifoid yaitu ceftriaxon (BPOM, 2015).

Pada penelitian ini juga ditemui penggunaan antibiotika golongan florokuinolon antara lain ciprofloxacin, levofloxacin dan moxifloxacin baik secara oral dan parenteral. Antibiotik ciprofloxacin oral sebanyak 5 pasien sedangkan ciprofloxacin parenteral sebanyak 6 pasien. Antibiotik levofloxacin oral sebanyak 1 pasien dan levofloxacin parenteral sebanyak 5 pasien. Antibiotik moxifloxacin sebanyak 5 pasien. Golongan florokuinolon merupakan antibiotika yang memiliki spektrum luas serta memiliki aktivitas kuat dalam menghambat bakteri gram positif dan bakteri gram negatif (BPOM, 2015).

Pada penelitian ini juga ditemui penggunaan antibiotik yang merupakan first-line terapi demam tifoid yaitu amoxiclav yang merupakan obat kombinasi antara amoxicillin 500mg dan asam klavulanik $125 \mathrm{mg}$, tetapi hanya ada 1 pasien yang menggunakan obat amoxicillin. Antibiotik amoxicillin merupakan antibiotik golongan penisilin yang bersifat bakterisida dan menghambat sintesis dinding sel (BPOM, 2015)

Antibiotik lain yang digunakan yaitu ada metronidazole sebanyak 1 pasien. Metronidazol merupakan antibiotik golongan nitroimidazoles yang merupakan antibiotik dengan aktivitas yang sangat baik terhadap bakteri anaerob dan protozoa (BPOM, 2015).

4.2. Aturan Penggunaan Antibiotik

Defined Daily Dose (DDD) adalah dosis harian rata-rata antibiotik yang digunakan pada orang dewasa untuk indikasi utamanya (WHO, 2019). Penggunaan antibiotik secara langsung dapat mempengaruhi tinggi rendahnya nilai DDD dari suatu jenis antibiotika. DDD Aturan penggunaan yang diberikan menentukan frekuensi penggunaan antibiotik yang diterima oleh pasien selama sehari. Semakin sering antibiotik digunakan dalam sehari maka frekuensi penggunaan antibiotik semakin tinggi. Hal ini akan meningkatkan jumlah dosis $(\mathrm{g})$ antibiotik yang diterima oleh pasien.

Tabel VI. Distribusi Aturan Penggunaan Antibiotik Pasien Demam Tifoid

\begin{tabular}{ccc}
\hline $\begin{array}{c}\text { Aturan } \\
\text { Pakai }\end{array}$ & $\begin{array}{c}\text { Jumlah Antibiotik } \\
\mathbf{N = 9 6}\end{array}$ & $\begin{array}{c}\text { Persentase (\%) } \\
\mathbf{N}=\mathbf{1 0 0 \%}\end{array}$ \\
\hline 1x1 Sehari & 26 & 27,1 \\
2x1 Sehari & 58 & 60,4 \\
3x1 Sehari & 12 & 12,5 \\
\hline Total & $\mathbf{9 6}$ & $\mathbf{1 0 0}$ \\
\hline & & (Data diolah, 2020)
\end{tabular}

Berdasarkan tabel diatas hasil penelitian ini menunjukkan bahwa aturan yang paling sering diterapkan adalah aturan $2 \times 1$ sehari dengan persentase $60,4 \%$ atau sebanyak 58 antibiotik hasil ini sama dengan penelitian sebelumnya oleh Nonita (2019) dengan persentase 93,5\%. Penerapan aturan pemakaian $>1$ x sehari akan meningkatkan jumlah dosis (g) antibiotika yang digunakan serta akan mempengaruhi nilai DDD (Carolina, 2014). Jenis Antibiotik yang menerapkan aturan penggunaan antibiotik $1 \times 1$ sehari terdiri dari antibiotik moxifloxacin, levofloxacin oral dan levofloxacin parenteral. Aturan penggunaan antibiotik $2 \times 1$ terdiri dari antibiotik ceftriaxon, cefim, ciprofloxacin oral dan ciprofloxacin parenteral. Sedangkan, antibiotik yang aturan penggunaan $3 \times 1$ terdiri dari antibiotik amoxicillin, cefotaxim, dan metronidazol.

4.3. Lama Penggunaan Antibiotik 
Lama penggunaan antibiotik untuk sebagian besar penyakit infeksi adalah selama 3-7 hari (Kemenkes, 2011). Umumnya pasien menjalani rawat inap di rumah sakit selama 7-9 hari.

Tabel VII. Jumlah lama hari rawat inap pasien demam tifoid di Instalasi Rawat Inap RSUD Kraton Pekalongan Tahun 2019.

\begin{tabular}{ccc}
\hline $\begin{array}{c}\text { Jumlah hari } \\
\text { rawat }\end{array}$ & $\begin{array}{c}\text { Jumlah Pasien } \\
\mathbf{N = 9 6}\end{array}$ & $\begin{array}{c}\text { Persentase }(\boldsymbol{\%}) \\
\mathbf{N}=\mathbf{1 0 0 \%}\end{array}$ \\
\hline 1-3 Hari & 23 & 24 \\
4-7 Hari & 70 & 72,9 \\
$>$ 8 Hari & 3 & 3,1 \\
\hline Total & $\mathbf{9 6}$ & $\mathbf{1 0 0 \%}$ \\
\hline Total LOS & \multicolumn{3}{|}{} \\
\hline
\end{tabular}

Berdasarkan tabel diatas sebagian besar pasien demam tifoid memiliki waktu rawat inap kurang dari 1 minggu. Lama rawat inap yang cepat disebabkan karena pasien telah mendapatkan pengobatan dan nutrisi yang baik serta mematuhi anjuran untuk istirahat yang cukup sehingga akan mempercepat lama rawat inap (Nurjanah, 2012).

Sedangkan untuk pasien yang menjalani rawat inap lebih dari 1 minggu disebabkan karena faktor dari beratnya penyakit yang dialami pasien (Dewi,2018). Pada perawatan demam tifoid normalnya yaitu 7-10 hari tetapi pada didapatkan hasil paling banyak yaitu perawatan selama 4-7 hari sebanyak 70 pasien.

Selama periode Januari-Desember 2019 tercatat bahwa total Length Of Stay dari 96 pasien yang terdiagnosis demam tifoid adalah 441 hari. Pada penelitian ini total LOS digunakan sebagai pembagi bersama nilai standar DDD WHO. Dimana banyaknya penggunaan antibiotik yang berlebihan akan mempengaruhi jumlah gram antibiotik yang digunakan oleh pasien dan akan berpengaruh pada tingginya nilai DDD yang melebihi standar WHO (WHO, 2019).

\section{Nilai DDD}

Penelitian ini yang mengenai evaluasi kuantitas penggunaan antibiotik pada pasien demam tifoid menggunakan acuan parameter dari Guideline For ATC Classification and DDD Assigment 2019. Parameter ini meliputi jumlah dan jenis antibiotik yang digunakan selama setahun. Hasil penelitian ini didapatkan 10 jenis antibiotik yang digunakan pada pasien demam tifoid yang di rawat di RSUD Kraton Pekalongan tahun 2019 dengan total nilai DDD/100 patient-days sebesar 68,71. Jenis antibiotik yang digunakan, kode ATC, nilai standar DDD WHO (g) dan nilai DDD/100 patient-days serta disajikan dalam Tabel VIII. 
Tabel VIII. Nilai DDD/100 Patient-days untuk masing-masing antibiotika beserta kode ATC dan standar DDD WHO

\begin{tabular}{ccccc}
\hline No & Nama Antibiotika & Kode ATC & $\begin{array}{c}\text { Nilai Standar } \\
\text { DDD WHO }(\mathbf{g})\end{array}$ & $\begin{array}{c}\text { Nilai DDD/100 } \\
\text { patient-days }\end{array}$ \\
\hline 1 & Amoxicillin & J01CA04 & 1 & 0,68 \\
2 & Cefotaxim & J01DD01 & 4 & 1,3 \\
3 & Ceftriaxon & J01DD04 & 2 & 45,23 \\
4 & Cefim & J01DD07 & 4 & 4,6 \\
5 & Ciprofloxacin & J01MA02 & 1 & 4 \\
& (Oral) & & & 3,4 \\
6 & Ciprofloxacin & J01MA02 & 0,8 & \\
& (Parenteral) & & & 0,22 \\
7 & Levofloxacin (Oral) & J01MA12 & 0,5 & 4,98 \\
8 & Levofloxacin & J01MA12 & 0,5 & 3,85 \\
& (Parenteral) & & & 0,45 \\
9 & Moxifloxacin & J01MA14 & 0,4 & $\mathbf{6 8 , 7 1}$ \\
10 & Metronidazol & J01XD01 & 1,5 & \\
\hline \multicolumn{7}{r}{} & Total
\end{tabular}

(Data diolah, 2020)

Berdasarkan hasil perhitungan DDD/100 patient-days pada penelitian ini diketahui bahwa dari 10 jenis antibiotik yang digunakan hanya 4 jenis antibiotik yang nilainya kurang dari yang telah ditetapkan oleh WHO (2019), yaitu antibiotik amoxicillin, cefotaxim, levofloxacin oral dan metronidazol.

Tingginya nilai DDD antibiotik yang tidak sesuai dengan standar WHO, menunjukkan bahwa penggunaan antibiotik masih ada yang tidak rasional. Semakin kecil hasil pengukuran kuantitas maka semakin rasional penggunaan antibiotika yang diberikan sehingga lebih sesuai dengan prinsip penggunaan antibiotik yang rasional (Laras, 2012).

Hal ini menandakan bahwa ketika kuantitas penggunaan antibiotik yang dinyatakan dalam nilai DDD lebih tinggi dan tidak sesuai dengan standar yang telah ditetapkan oleh WHO penggunaan antibiotik maka peresepan dan penggunaan antibiotik pada pasien dikatakan tidak rasional sehingga dikhawatirkan akan banyak ditemuinya peresepan dan penggunaan antibiotik yang tidak tepat pemberian (Nonita, 2017). Tingginya nilai DDD dipengaruhi oleh jumlah gram pemakaian antibiotik yang diberikan berlebihan pada pasien karena apabila antibiotik yang diberikan berlebihan maka nilai DDD akan cenderung lebih tinggi dibandingkan dengan nilai standar DDD yang telah ditetapkan (WHO, 2019).

Pada penelitian ini seperti pada Tabel diatas bahwa penggunaan antibiotik yang paling banyak digunakan di Instalasi Rawat Inap RSUD Kraton Pekalongan tahun 2019 untuk pasien dewasa demam tifoid adalah golongan sefalosporin generasi ketiga yaitu ceftriaxon, hal ini karena ceftriaxon memiliki stabilitas yang tinggi terhadap bakteri gram negatif maupun gram positif yang baik sehingga lebih efektif untuk terapi demam tifoid (Nonita, 2017).

Pada penelitian ini beberapa antibiotik yang nilai DDD-nya melebihi standar WHO yaitu antibiotik ceftriaxon $(45,23)$, cefim $(4,6)$, ciprofloxacin oral (4), ciprofloxacin parenteral $(3,4)$, levofloxacin parenteral $(4,98)$ dan moxifloxacin $(3,85)$. Sebagian besar antibiotik tersebut aturan pemakaiannya $2 \times 1$ sehari, sementara amoxicillin dan cefim aturan pemakaiannya $3 \times 1$ sehari, selain frekuensi aturan pemakaian lama penggunaan antibiotik juga mempengaruhi nilai DDD yang didapatkan. 


\section{KESIMPULAN}

Hasil evaluasi kuantitas penggunaan antibiotik pada pengobatan pasien demam tifoid di Instalasi rawat inap RSUD Kraton Pekalongan tahun 2019 yaitu antibiotik yang sering diberikan adalah antibiotik golongan sefalosporin generasi ketiga yaitu ceftriaxon dengan jumlah DDD/100 patient-days sebesar 45,23, hal ini tidak sesuai dengan standar WHO yang telah ditetapkan.

\section{UCAPAN TERIMAKASIH}

Puji syukur penulis panjatkan kepada Allah SWT, karena berkat kelimpahan rahmat, hidayah dan karunia-Nya penelitian ini yang berjudul "Evaluasi Kuantitas Penggunaan Antibiotik pada Pasien Demam Tifoid di Instalasi Rawat Inap RSUD Kraton Pekalongan Tahun 2019" dapat terselesaikan, selain itu Penulis mengucapkan terimakasih kepada Universitas Muhammadiyah Pekajangan Pekalongan, Dosen Pembimbing, Dosen Penguji, RSUD Kraton Pekalongan, BAPPEDA, Orang tua dan sahabat serta semua pihak yang banyak memberikan dukungan dan bantuan serta doanya Penulisan skripsi ini dilakukan sebagai tahapan dalam penyelesaian syarat untuk mencapai gelar Sarjana Farmasi pada Program Studi Sarjana Farmasi, Fakultas Ilmu Kesehatan Universitas Muhammadiyah Pekajangan Pekalongan. Shalawat serta salam senantiasa terlantunkan kepada nabi Muhammad SAW yang dinantikan syafa'atnya kelak di akhirat.

\section{DAFTAR PUSTAKA}

Adiputra, I Komang Gede Triana; Somia, I ketut agus. (2017). Karakteristik Klinis Pasien Demam Tifoid Di RSUP Sanglah Periode Waktu Juli 2013 - Juli 2014. E-Jurnal Medika Udayana, S.1, v.6, n. 11, p. 98-102. ISSN 2303-1395.

Badan Pengawas Obat dan Makanan (BPOM). 2015. Pusat Informasi Obat Nasional. Statin. Pionas.pom.go.id. dikutip 30 Juni 2020.

Carolina. 2014. Skripsi. Evaluasi Penggunaan Antibiotika Dengan Metode DDD Pada Pasien Anak Di Rawat Inap Bangsal Inska II RSUP DR. Sardjito Yogyakarta Periode JanuariJuni 2013. Universitas Sanata Darma. Yogyakarta.

Dewi, L., A. 2018. Skripsi. Evaluasi Penggunaan Antibiotik Pada Pasien Demam Tifoid Rawat Inap Di Rumah Sakit Islam Klaten Tahun 2017. Universitas Setia Budi. Surakarta.

Hermayudi dan Ayu, P.A. 2017. Penyakit Daerah Tropis. Nuha Medika. Yogyakarta.

Jahja, Yudrik. 2011. Psikologi Perkembangan. Prenada Media. Jakarta.

Kementerian Kesehatan Republik Indonesia. 2011. Pedoman Pelayanan Kefarmasian Untuk Terapi Antibiotik. Direktorat Jenderal Bina Kefarmasian dan Alat Kesehatan. Jakarta.

Laras,N.W. 2012. Kuantitas Penggunaan Antibiotik di Bangsal Bedah dan Obsgin RSUP DR. Kariadi setelah Kampanye Program Pencegahan Pengendalian Resistensi Antibiotika (PP-PPRA). Skripsi. Universitas Diponegoro, Semarang.

Nonita, R.2019. Evaluasi Penggunaan Antibiotika Pada Kasus Demam Tifoid Di Rumah Sakit Panti Rini. Skripsi. Universitas Sanata Dharma. Yogyakarta.

Nurjanah, S., Rohadi, H., Anita, A. 2012. Faktor-Faktor Yang Berhubungan Dengan Lama Hari Rawat Anakpost Appendectomy. Universitas Muhammadiyah Jakarta. Jakarta. 
Patattan, S. 2017. Evaluasi Penggunaan Antibiotik Pada Pasien Demam Tifoid rawat inap stella Maris Makassar pada Tahun 2016. Skripsi. Universitas Sanata Dharma. Yogyakarta.

Peraturan Menteri Kesehatan Republik Indonesia Nomor 2406/MENKES/PER/XII/2011. Tentang Pedoman Umum Penggunaan Antibiotik. Jakarta.

Pramitasari, O.P. 2013. Faktor Resiko Kejadian Penyakit Demam Tifoid Pada Penderita Yang Dirawat Di Rumah Sakit Ungaran. Journal Kesehatan Masyarakat 2 : 1-10

Prasetyono, D.S. 2012. Daftar Tanda dari Gejala Ragam Penyakit. Diva Press.Yogyakarta.

Purwaningsih, A., Rahmawati, F., Wahyono, D., 2015. Evaluasi Penggunaan Antibiotik Pada Pasien Pediatri Rawat Inap. Jurnal Manajemen dan Pelayanan Farmasi., 5 (3), 214.

World Health Organization (WHO). 2019. Guidelines For ATC Classification and DDD assignment 2020. Oslo.

Widodo, D. 2009. Demam tifoid buku ajar penyakit dalam, Interna Publishing. Jakarta.

Widoyono. 2011. Penyakit Tropis : Epidemiologi, Penularan, Pencegahan, dan Pemberantasannya. Erlangga. Jakarta. 
